\title{
PERAN KEUNGGULAN BERSAING SEBAGAI MEDIASI PENGARUH INOVASI DAN ORIENTASI PASAR TERHADAP KEPUASAN PELANGGAN
}

\author{
Junida Putra Ananta Bakti, Fatchur Rohman, Sunaryo \\ Universitas Brawijaya Malang \\ Email : Junidaputra@gmail.com
}

\begin{abstract}
This research aims to investigate the role of competitive advantage as mediator in the effect of innovation and market orientation to customer satisfaction at PT. Holcim Beton, Surabaya. While competitive advantage variable consists of competitive ability, human resource, and marketing relationship, Innovation variable involves product innovation, and process innovation. In addition, the indicator of market orientation includes customer orientation and responsiveness. Furthermore, the whole satisfaction and hope confirmatory, both of them are for customer satisfaction variable. This research uses Partial Least Square (PLS) as a method of data analysis. Based on the test, this research found that; first, innovation directly effects customer satisfaction; second, market orientation significantly influence customer satisfaction; third, innovation and market orientation indirectly and significantly affect customer satisfaction through competitive advantage. Therefore, to get customer satisfaction, competitive advantage can mediate innovation and market orientation. This research implies when PT. Holcim Beton Surabaya make more innovation and market orientation continuously rather than competitors, it will be able to have a competitive advantage and able to satisfy the customers.
\end{abstract}

\section{Keywords: competitive advantage, innovation, market orientation, and customer satisfaction}

\begin{abstract}
Abstrak : Penelitian ini bertujuan untuk mengetahui peran keunggulan bersaing sebagai mediasi pengaruh inovasi produk dan orientasi pasar terhadap kepuasan pelanggan pada PT. Holcim Beton Surabaya. Variabel keunggulan bersaing yang diteliti meliputi kemampuan bersaing, sumber daya manusia, dan relationship marketing. Variabel inovasi sendiri meliputi inovasi produk dan inovasi proses. Variabel orientasi pasar meliputi orientasi pelanggan dan responsiveness. Sedangkan untuk variabel kepuasan pelanggan meliputi kepuasan keseluruhan dan konfirmasi harapan. Penelitian ini menggunakan PLS sebagai metode analisis data. Berdasarkan hasil pengujian, inovasi secara langsung memiliki pengaruh signifikan terhadap kepuasan pelanggan. Orientasi pasar memiliki pengaruh signifikan terhadap kepuasan pelanggan. Inovasi dan orientasi pasar secara tidak langsung berpengaruh signifikan terhadap kepuasan pelanggan melalui keunggulan bersaing. Dengan begitu keunggulan bersaing bisa dijadikan mediasi inovasi dan orientasi pasar untuk mendapatkan kepuasan pelanggan. Dengan begitu, ketika PT. Holcim Beton Surabaya melakukan inovasi serta melakukan orientasi pasar yang secara terus menerus yang mana hal tersebut belum dilakukan oleh perusahaan pesaing, maka keunggulan bersaing bisa didapatkan oleh perusahaan yang pada akhirnya akan mendapatkan kepuasan dari pelanggan.
\end{abstract}

Kata Kunci: Keunggulan bersaing, inovasi, orientasi pasar, kepuasan pelanggan 


\section{PENDAHULUAN}

Pada zaman globalisasi seperti saat ini, persaingan di dunia bisnis tidak dapat dihindari lagi. Lingkungan persaingan yang semakin ketat perlu diperhatikan dan disikapi dengan baik, agar perusahaan swasta dapat terus bertambah banyak dan bahkan bisa lebih kompetitif dalam persaingan. Dalam hal ini perusahaan harus mempunyai keunggulan bersaing yang tinggi agar dapat bertahan dan berjalan dengan baik. Porter (1990 : 20) menyebutkan bahwa faktor penentu keunggulan kompetitif suatu perusahaan adalah : a) Kondisi permintaan, dan b) Industri yang terkait dan industri penunjang. Serta dua faktor ekternal yaitu, penemuan baru dan faktor-faktor dari pemerintah.

Pada dasarnya untuk memenuhi permintaan pasar, perusahaan berusaha menciptakan sesuatu hal yang baru, atau produk baru yang bisa disebut produk inovasi. Sehingga, produk inovasi merupakan salah satu yang dapat digunakan sebagai keunggulan kompetitif bagi perusahaan (Ferry Jie Kevin, 2013). Produk inovasi sebagai hasil dari keinovatifan yang bermutu tinggi yang diperlukan oleh pelanggan, baik berupa pengembangan dari lini produk yang ada, ataupun produk yang benar-benar baru bagi pasar juga merupakan salah satu strategi dalam pencapaian. Silvadas \& Dwyer (2010), menyebutkan bahwa produk baru akan dapat meningkatkan penjualan, laba dan keunggulan kompetitif perusahaan.

Dalam membuat inovasi produk, suatu perusahaan harus memperhatikan orientasi pasar, sebab pengetahuan tentang hal tersebut merupakan kunci sukses inovasi produk yang akan dihasilkan. Kohli dan Jaworski (dalam Hurley dan Hult, 2013. P. 43) mendefinisikan orientasi pasar sebagai pencipta kecerdasan pasar (Market Intellingent) dilihat organisasi yang memahami kebutuhan konsumen pada saat ini dan masa yang akan datang, penyebaran kecerdasan di antara departemen dan daya tanggap organisasi secara menyeluruh. Adanya kompleksitas dan dinamika lingkungan bisnis yang meningkat secara intens telah mendorong perusahaan-perusahaan untuk memperkuat basis strategi dengan konsep yang fokus pada pelanggan agar mereka tetap dapat mengakses pasarnya dan menjamin pertumbuhan berkelanjutan.

Kepuasan (satisfaction) adalah perasaan senang atau kecewa seseorang yang muncul setelah membandingkan kinerja yang dipersepsikan produk (atau hasil) terhadap ekpektasi mereka (Kotler, 2009). Oleh karena itu, kepuasan berkaitan erat dengan harapan konsumen. Lebih khusus lagi, kesenjangan antara harapan konsumen dan kinerja aktual dari produk atau layanan adalah kepuasan konsumen (Hutcheson dan Moutinho, dalam penelitian Ilias Santouridis and Panagiotis Trivellas, 2010). Mowen dalam Tjiptono (2007) merumuskan kepuasan pelanggan sebagai sikap keseluruhan terhadap suatu barang atau jasa setelah perolehan (acquisition) dan pemakaiannya. Dengan kata lain, kepuasan pelanggan merupakan penilaian evaluatif purnabeli yang dihasilkan dari seleksi pembelian spesifik.

Menurut (Tahir Naveed, 2012). kepuasan pelangan merupakan konstruk (faktor) yang umum digunakan untuk mengukur kesuksesan dari sebuah strategi perusahaan. Narver dan Slater (2008, p. 134) menyatakan perusahaan yang telah menjadikan orientasi pasar sebagai budaya organisasi akan berfokus pada kebutuhan pasar eksternal, keinginan dan permintaan pasar sebagai basis dalam penyusunan strategi bagi masing-masing unit bisnis dalam organisasi dan menentukan keberhasilan perusahaan.

Seiring dengan perkembangan di bidang teknologi rekayasa struktur di Indonesia, penggunaan beton masih banyak digunakan pada pekerjaan konstruksi seperti bangunan tinggi, jalan, bendungan dll. Beton merupakan bahan yang relatif murah dibandingkan dengan bahan lain, selain memiliki kuat tekan yang besar, beton itu mudah untuk dikerjakan dan dapat dibentuk sesuai dengan yang diinginkan. Fenomena dari Inovasi dalam dunia modern ini tentunya sudah banyak di terapkan di Indonesia, salah satunya oleh PT. Holcim beton. Sejalan dengan perkembangan beton, maka banyak pula metode untuk mendesain campuran beton. Metode campuran beton dituntut untuk memperhatikan hal-hal sebagai berikut : pembuatan beton yang sesuai dengan kebutuhan bangunan yang direncanakan, bahan pengisi (filler) beton terbuat dari bahan-bahan yang mudah diperoleh, kekuatan dari beton yang dihasilkan (strenght), kemudahan dalam proses pengerjaan (workability) dan keawetannya (durability). Dalam pembangunan gedung-gedung bertingkat tinggi dibutuhkan beton kekuatan tinggi, beton mutu tinggi merupakan pilihan yang tepat. 
Semakin banyaknya perusahaanperusahaan beton berdiri, maka persaingan pun akan semakin sengit. Dengan pembangunanpembangunan yang berjalan secara terus menerus, terutama di Negara berkembang seperti Indonesia ini, maka kebutuhan betonpun bukannya malah berkurang, tapi akan semakin bertambah permintaanya. Disinilah PT. Holcim devisi beton membuat inovasi untuk memenuhi kebutuhan dari pasar atau konsumen yang menginginkan beton yang sudah bisa di gunakan dalam jangka waktu sesingkat mungkin. Mengingat biasanya beton baru bisa digunakan setelah hari ke 29 setelah pengecoran. Untuk itu maka diciptakanlah beton cepat kering atau sering di sebut speeedcrete. Beton ini merupakan inovasi yang pertama kali diciptakan oleh PT. Holcim beton, dimana beton tersebut hanya dalam hitungan jam saja sudah bisa di lewati atau di gunakan. Hal ini tentunya sesuai dengan apa yang di inginkan oleh konsumen diluar sana, yang berharap adanya inovasi yang di lakukan oleh perusahaan-perusahaan penyedia beton. Dengan adanya inovasi ini, yang didasari oleh orientasi pasar, diharapkan adanya keunggulan bersaing, yang akan mengakibatkan kepuasan pelanggan.

Banyak penelitian yang mengangkat tentang peran inovasi terhadap kepuasan konsumen, ataupun juga orientasi pasar terhadap kepuasan konsumen. Jarang ada penelitian yang mengangkat tentang apakah ada peran dari faktor-faktor lain yang bisa memediasi antara inovasi dan orientasi pasar terhadap kepuasan konsumen. Dalam penelitian ini, peneliti mencoba untuk menguji peran dari keunggulan bersaing dalam hubungan inovasi dan orientasi pasar terhadap kepuasan konsumen.

Dalam beberapa penelitian terdahulu, Tahir Naveed, et al (2012) menyatakan bahwa keunggulan bersaing bisa menjadi faktor yang memediasi inovasi dalam menciptakan kepuasan konsumen, akan tetapi dalam penelitian tersebut belum di buktikan lebih lanjut secara empiris. Dalam Riza Casidy (2014) terkait dengan variabel orientasi pasar diasumsikan bahwa secara positif dan signifikan terdapat pengaruh terhadap kepuasaan konsumen, namun demikian, dalam penelitian tersebut menyebutkan perlu adanya pengujian lebih lanjut yang berhubungan dengan mediator keunggulan bersaing untuk mengetahui secara mendalam apakah memang benar-benar tetap berpengaruh signifikan atau tidak antara orientasi pasar dan kepuasaan konsumen.

Berangkat dari uraian diatas, peneliti ingin membuktikan bahwa keunggulan bersaing bisa menjadi variabel yang memediasi pengaruh inovasi produk dan orientasi pasar terhadap kepuasan konsumen. Selain dilatar belakangi hal diatas, alasan lain yang memperkuat bahwa penelitian ini menarik untuk dilakukan adalah adanya penelitian yang membuktikan bahwa keunggulan bersaing secara signifikan mempengaruhi kepuasan konsumen (Baker \& Sinkula (2013), Wen-Yu Tsao (2014)) akan tetapi dalam penelitian tersebut, mereka tidak menambahkan faktorfaktor seperti inovasi dan orientasi pasar. Di dalam penelitian ini, semua aspek-aspek tersebut di gabungkan menjadi satu, untuk melihat apakah hal tersebut berpengaruh signifikan ataukah sebaliknya.

\section{HIPOTESIS Inovasi}

Inovasi bisa merupakan produk baru atau konsep baru yang telah diperoleh dari penelitian sistematis dan ide baru (Tahir Naveed 2012). Hal ini juga didefinisikan sebagai komersialisasi penciptaan. Inovasi juga digambarkan sebagai proses konversi penemuan atau ide menjadi produk yang akan di beli oleh konsumen dan memberikan keuntungan kepada penyedia nya. Produk inovasi dapat gagal karena hanya alasan, tidak menawarkan desain yang unik atau salah perkiraan persaingan yang merupakan kesalahan umum terjadi dengan adanya inovasi produk maka akan memberikan nilai tambah dibanding produk sejenis (keunggulan Produk) sehingga akan meningkatkan kinerja pemasaran.

H1: Semakin tinggi Inovasi yang dilakukan maka akan semakin tinggi keunggulan bersaing.

\section{Orientasi Pasar}

Orientasi pasar dan inovasi adalah inti dari strategi kapabilitas dari bisnis yang berbasisi pasar, semestinya penerapan orientasi pasar dan inovasi, mungkin menjadi hubungan yang signifikan dengan menguji mata rantai antara orientasi pasar dan inovasi, kita dapat mengembangkan pengetahuan yang baik dari hubungan anatara strategi kapabilitas tersebut. Riza Casidy (2014) mengatakan bahwa 
orientasi pasar berpengaruh positif terhadap kepuasan pelanggan. Orientasi pasar berpengaruh positif terhadap produk inovatif melalui koordinasi antara fungsi, kondisi ini dapat dimengerti karena dengan adanya koordinasi antar fungsi pemasaran dengan fungsi lain didalam proses akan menimbulkan satu pemahaman yang sama tentang kebutuhan dari pelanggan.

$\mathrm{H} 2$ : Semakin tinggi Orientasi pasar maka akan semakin tinggi keunggulan bersaing.

\section{Keunggulan Bersaing}

Calantone (2010, p. 53) menyatakan bahwa indikator dari keunggulan bersaing produk baru terdiri dari : kualitas, tahan uji, kebaruan produk, dan keunikan produk Keunggulan bersaing adalah jantung kinerja perusahaan dalam pasar bersaingan. Keunggulan bersaing pada dasarnya tumbuh dari nilai atau manfaat yang dapat menciptakan perusahaan bagi pembelinya. Bila perusahaan kemudian mampu menciptakan keunggulan melalui salah satu dari tiga strategi generik tersebut, maka akan didapatkan keunggulan bersaing.

H3 : Semakin tinggi Kunggulan bersaing maka akan semakin tinggi kepuasan konsumen

\section{Kepuasan Pelanggan}

Hasil penelitian dari Tahir Naveed and Irum Akhtar (2012) menyatakan bahwa inovasi berpengaruh signifikan terhadap kepuasan para pelanggan, hal bisa terjadi dikarenakan konsumen merasa di perhatikan oleh perusahaan atas apa yang mereka inginkan. Begitu juga penelitian yang dilakukan oleh Liem Viet Ngo and Aron O'Cass (2012) yang juga menyatakan bahwa inovasi memiliki efek positif terhadap kepuasan pelanggan.

H4 : Semakin tinggi Inovasi maka semakin tinggi kepuasan konsumen.

Hasil penelitian dari Carmen Barroso Castro, Enrique Martı'n Armario (2004) menyatakan bahwa orientasi pasar sangat berpengaruh terhadap keupasan konsumen. Begitu juga penelitian yang dilakukan oleh Reza Casidy (2014) di Australia, peneitian tersebut juga mengungkapkan hal yang sama dengan penelitian sebelumnya, yaitu orientasi pasar berpengaruh positif terhadap kepuasan konsumen.

H5 : Semakin tinggi orientasi pasar, semakin tinggi kepuasan konsumen.

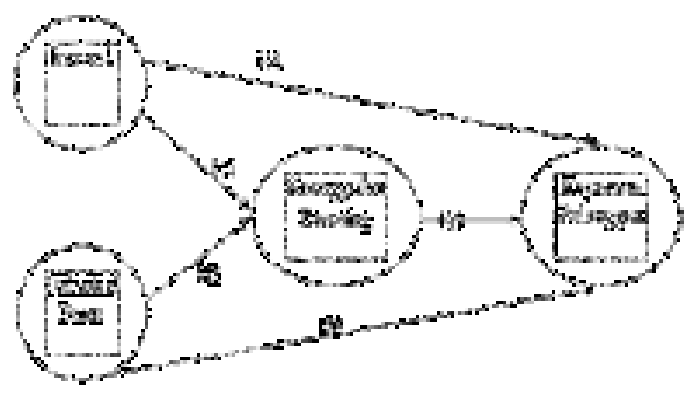

METODE

Dalam penelitian ini analisis data menggunakan pendekatan Partial Least Square (PLS). Alasan penggunaan Partial Least Square (PLS) karena dengan alat ini dimungkinkan melakukan pemodelan persamaan structural dengan ukuran sampel relative kecil dan tidak membutuhkan asumsi normal multivariate. Ghozali (2012) menyatakan PLS merupakan metode analisis yang powerful karena dapat diterapkan pada semua skala data. PLS selain dapat digunakan sebagai konfirmasi teori juga dapat digunakan untuk membangun hubungan yang belum ada landasan teorinya atau untuk pengujian proposisi.

Populasi untuk penelitian ini adalah masyarakat di Surabaya yang pernah melakukan pembelian beton Speedcrete untuk pembangunan fasilitas umum maupun kebutuhan pribadi minimal sebanyak 2 kali. Pupulasi dalam penelitian ini diketahui sebanyak 215. Teknik pengambilan sampel adalah cara peneliti mengambil sampel atau contoh yang representatif dari populasi yang tersedia (Sanusi, 2011:88). Karena jumlah populasi yang akan diteliti sudah diketahui secara pasti yaitu sebanyak 213 orang, maka penelitian ini menggunakan rumus Slovin dalam Husein (1998:78) dan didapatkan jumlah sampel sebesar 143 orang. Teknik pengambilan sampel dari penelitian ini purposive sampling. Purposive sampling adalah teknik penentuan sampel dengan pertimbangan tertentu (Sugyono, 2012:122).

Data yang digunakan adalah data primer dan data sekunder. Pengumpulan data dilakukan dengan cara memberi kuisioner (daftar pernyataan) kepada responden dan mereka hanya menjawab sesuai dengan pilihan jawaban dalam daftar pernyataan tersebut. Kuesioner akan disebarkan secara fisik kepada pelanggan Holcim beton di Kota Surabaya yang telah membeli beton sebagai bahan bangunannya. Statistik deskriptif digunakan 
untuk menjelaskan data dari suatu variable yang diteliti. Data yang dikumpulkan dikelompokkan dan disusun ke dalam kelaskelas tertentu, melalui distribusi frekuensi. Distribusi frekuensi itu sendiri adalah susunan data menurut kelas-kelas interval tertentu atau kategori tertentu dalam sebuah daftar (Sanusi, 2011:116).

Pengujian hipotesis tentang variabel mediasi dilakukan dengan prosedur Uji Sobel (Sobel Test) (Baron dan Kenny 1986). Uji Sobel berkenaan dengan menguji signifikansi koefisien jalur pengaruh tidak langsung. Pada penelitian untuk studi tesis ini digunakan taraf nyata $\alpha=0,05$.

\section{HASIL}

Tahapan awal dari penelitian adalah menentukan tingkat validitas dari penelitian ini sendiri. Validitas konvergen diketahui melalui loading factor. Suatu instrumen dikatakan memenuhi pengujian validitas konvergen jika memiliki loading faktor di atas 0.6. Hasil pengujian validitas konvergen disajikan dalam Tabel berikut:

Tabel 1

Uji Validitas Konvergen

\begin{tabular}{ccccc}
\hline Variabel & Indikator & Loading Factor & Cut Off & Keterangan \\
\hline \multirow{2}{*}{ Inovasi } & $\mathrm{X} 1.1$ & 0.863 & 0,6 & Valid \\
\cline { 2 - 5 } & $\mathrm{X} 1.2$ & 0.838 & 0,6 & Valid \\
\hline \multirow{2}{*}{ Orientasi Pasar } & $\mathrm{X} 2.1$ & 0.898 & 0,6 & Valid \\
\cline { 2 - 5 } & $\mathrm{X} 2.2$ & 0.801 & 0,6 & Valid \\
\hline \multirow{2}{*}{ Kepuasan Konsumen } & $\mathrm{Y} .1$ & 0.885 & 0,6 & Valid \\
\cline { 2 - 5 } & $\mathrm{Y} .2$ & 0.814 & 0,6 & Valid \\
\hline \multirow{3}{*}{ Keunggulan Bersaing } & $\mathrm{Z} .1$ & 0.675 & 0,6 & Valid \\
\cline { 2 - 5 } & $\mathrm{Z} .2$ & 0.842 & 0,6 & Valid \\
\cline { 2 - 5 } & $\mathrm{Z} .3$ & 0.711 & 0,6 & Valid \\
\hline
\end{tabular}

Sumber: Data Penelitian Diolah (2016)

Hasil pada tabel 5.7 menginformasikan bahwa semua item yang mengukur inovasi, orientasi pasar, kepuasan konsumen, dan keunggulan bersaing memiliki nilai loading factor diatas 0.6 , sehingga semua item dalam instrumen dinyatakan valid dalam mengukur tiap-tiap variabel.

Validitas konvergen dapat diketahui melalui nilai Average Variance Extracted
(AVE) dan communality. Sebuah instrumen dinyatakan valid secara konvergen, jika nilai AVE dan communality untuk setiap variabel diatas 0.5 (Chin, 1995 dalam Jogiyanto dan Abdillah, 2009). Hasil pengujian validitas konvergen berdasarkan nilai AVE dan communality disajikan pada tabel 5.8.

Tabel 2

Hasil Uji Validitas Konvergen Berdasarkan Nilai AVE dan Communality

\begin{tabular}{ccccc}
\hline Variabel & AVE & Communality & Cut Off & Keterangan \\
\hline Inovasi & 0.723 & 0.723 & 0.5 & Valid \\
\hline Orientasi Pasar & 0.724 & 0.724 & 0.5 & Valid \\
\hline Keunggulan Bersaing & 0.723 & 0.723 & 0.5 & Valid \\
\hline Kepuasan Pelanggan & 0.557 & 0.557 & 0.5 & Valid \\
\hline
\end{tabular}

Sumber: Data primer diolah, 2016

Hasil dari tabel 2 menginformasikan bahwa variabel inovasi, orientasi pasar, kepuasan konsumen, dan keunggulan bersaing memiliki nilai AVE dan communality di atas 0.5 . Hasil tersebut menunjukkan bahwa tiap item dalam sebuah instrumen dinyatakan valid dalam mengukur tiap-tiap variabel.

Dasar pengambilan keputusan untuk pengujian hipotesis adalah dengan menggunakan uji $\mathrm{T}$ Statistik, di mana nilai $\mathrm{T}$ 
Statistik yang lebih besar dari nilai $\mathrm{T}$ Tabel 1.96 menunjukkan pengaruh yang signifikan.

Tabel 3

Pengujian Hipotesis Antar Variabel

\begin{tabular}{cccccc}
\hline Hipotesis & Pengaruh & Koefisien & Std. Error & T Statistik & Keterangan \\
\hline 1 & $\mathrm{X} 1 \rightarrow \mathrm{Z}$ & 0.306 & 0.069 & 4.459 & Signifikan \\
\hline 2 & $\mathrm{X} 2 \rightarrow \mathrm{Z}$ & 0.495 & 0.059 & 8.318 & Signifikan \\
\hline 3 & $\mathrm{Z} \rightarrow \mathrm{Y}$ & 0.396 & 0.071 & 5.567 & Signifikan \\
\hline 4 & $\mathrm{X} 1 \rightarrow \mathrm{Y}$ & 0.200 & 0.061 & 3.270 & Signifikan \\
\hline 5 & $\mathrm{X} 2 \rightarrow \mathrm{Y}$ & 0.305 & 0.057 & 5.303 & Signifikan \\
\hline 6 & $\mathrm{X} 1 \rightarrow \mathrm{Z} \rightarrow \mathrm{Y}$ & 0.121 & 0.035 & 3.447 & Signifikan \\
\hline 7 & $\mathrm{X} 2 \rightarrow \mathrm{Z} \rightarrow \mathrm{Y}$ & 0.196 & 0.043 & 4.603 & Signifikan \\
\hline
\end{tabular}

Sumber: Data Penelitian Diolah (2016)

Pada tabel 3 diatas, berdasar pengujian hipotesis antar variabel yang sudah dilakukan, di dapatkan hasil yang signifikan pada semua hipotesis. Hal ini menujukkan bahwa antar variabel tersebut memang saling berpengaruh positif dan sesuai dengan teori serta jurnal yang digunakan sebagai dasar penelitian ini.

\section{PEMBAHASAN \\ Pengaruh Inovasi Terhadap Keunggulan Bersaing}

Hasil penelitian menunjukkan bahwa inovasi memiliki pengaruh terhadap keunggulan bersaing. Makna temuan ini adalah dengan meningkatnya inovasi yang dilakukan oleh PT. Holcim Beton Surabaya berdasarkan indikator inovasi produk dan inovasi proses, maka akan meningkatkan keunggulan bersaing pada PT. Holcim Beton Surabaya. Hasil ini sesuai dengan hasil penelitian yang dilakukan oleh Nurul Nadia and Abd Aziz (2016) dan Kevin. (2013) yang menyatakan bahwa inovasi memiliki pengaruh terhadap Keunggulan bersaing.

Sebagian besar responden merasakan dampak inovasi yang diberikan oleh PT. Holcim Beton Surabaya, sehingga responden merasa ketika perusahaan melakukan inovasi secara terus menerus, maka dengan sendirinya perusahaan akan menjadi perusahaan yang unggul dibandingkan dengan perusahaan lainnya. Hal ini dikarenakan adanya keunikan tersendiri atau keunggulan tersendiri dibandingkan perusahaan lain.

\section{Pengaruh Orientasi Pasar Terhadap Keunggulan Bersaing}

Hasil penelitian menunjukkan bahwa orientasi pasar memiliki pengaruh terhadap keunggulan bersaing. Hasil ini sesuai dengan hasil penelitian yang dilakukan oleh Kevin Zheng (2009) yang menyatakan bahwa orientasi pasar memiliki pengaruh terhadap keunggulan bersaing.

Pelayanan yang baik dan berkualitas dari perusahaan kepada pelanggan, sering dianggap sebagai cara yang paling mudah untuk menggali informasi dari pelanggan tentang apa yang dibutuhkan oleh pelanggan saat ini. Dengan begitu perusahaan akan bisa menciptakan suatu produk yang sejalan dengan apa yang diinginkan oleh pelanggan, sehingga pelanggan menjadi bagian dari perusahaan dalam penciptaan produk-produk baru. Selain itu juga hubungan baik antara perusahaan dan pelanggan harus dijaga dengan baik, agar menimbulkan kenyamanan bagi kedua belah pihak.

\section{Pengaruh Keunggulan Bersaing Terhadap Kepuasan Pelanggan}

Hasil penelitian menunjukkan bahwa keunggulan bersaing memiliki pengaruh terhadap kepuasan pelanggan. Hasil ini sesuai dengan hasil penelitian yang dilakukan oleh Wen-yu Tsao (2014) dan Nelson Oly (2005) yang menyatakan bahwa keunggulan bersaing memiliki pengaruh terhadap kepuasan pelanggan.

Relationship marketing memiliki penilaian yang cukup tinggi menurut pelanggan dikarenakan pelanggan menilai bahwa perusahaan memberikan perhatian khusus kepada mereka, dengan selalu menginformasikan produk baru, layanan baru ataupun jika ada perubahan harga pada produk dari PT. Holcim Beton Surabaya. Sehingga, 
pelanggan tidak akan tertinggal dalam hal informasi, mengingat informasi merupakan salah satu aspek dalam mementukan pilihan dalam memilih produk. Untuk sumber daya manusia, juga memiliki nilai yang cukup tinggi menurut pelanggan dikarenakan kemampuan dari karyawan PT. Holcim Beton Surabaya dalam melayani pelanggan yang baik, sehingga pelanggan merasa aman dalam melakukan transaksi ataupun ketika menghadapi berbagai kendala yang berhubungan dengan masalah beton. Pelanggan menilai sumber daya manusia yang ada di dalam perusahaan cukup cakap dalam menjawab dan membantu permasalahan yang ada, sehingga pelanggan tidak mempunyai kekhawatiran yang berlebih ketika tidak mengetahui cara-cara yang benar dalam menangani masalah masalah beton.

\section{Pengaruh Inovasi Terhadap Kepuasan Pelanggan}

Makna temuan ini adalah dengan meningkatnya inovasi yang dilakukan oleh PT. Holcim Beton Surabaya berdasarkan indikator inovasi produk dan inovasi proses, maka akan meningkatkan kepuasan pelanggan pada PT. Holcim Beton Surabaya. Hasil ini sesuai dengan hasil penelitian yang dilakukan oleh Liem Viet (2012) dan Tahir znaveed (2012) yang menyatakan bahwa inovasi memiliki pengaruh terhadap kepuasan pelanggan.

Berdasarkan indikator-indikator inovasi yaitu inovasi produk dan inovasi proses, pada penelitian ini inovasi produk memiliki milai rata-rata yang lebih tinggi daripada inovasi proses. Dalam hal ini inovasi produk memiliki nilai yang lebih tinggi dikarenakan para pelanggan menilai produk baru yang dihasilkan dirasa sangat bermanfaat. Selain itu, produk baru yang diciptakan oleh PT. Holcim Beton surabaya merupakan produk yang berbeda dari produk-produk lainnya serta sesuai dengan apa yang mereka. Pada saat perusahaan menciptakan atau mengeluarkan produk baru, pelanggan biasanya terlebih dahulu membandingkannya dengan produk yang sama dari perusahaan yang berbeda, lalu pelanggan akan memilih mana yang akan mereka gunakan. Apabila produk yang diproduksi oleh perushaan ternyata tidak memiliki kesamaan dengan produk pesaing ataupun memiliki suatu keunggulan tertentu, hal ini bisa membuat pelanggan terhadap produk yang telah di produksi oleh PT. Holcim Beton Surabaya.
Pelanggan dari PT. Holcim beton sendiri memiliki keterlibatan yang tinggi terhadap inovasi proses yang dilakukan oleh perusahaan. Inovasi proses sendiri diperlukan untuk mendapatkan perhatian dari pelanggan, inovasi proses digunakan oleh perusahaan untuk melayani dan langsung bersentuhan dengan kosumen, sehingga perusahaan bisa mendapatkan gambaran tentang pelayanan perusahaan dengan pelayanan perusahaan lain dengan informasi yang di dapatkan dari pelanggan lalu memperbaiki atau mempermudah segala sesuatu untuk kenyamanan pelanggan dibandingkan dengan pesaing. Hasil ini menunjukkan bahwa PT. Holcim Beton Surabaya dinilai memiliki inovasi produk maupun inovasi proses yang baik dihadapan konsumen. Pelanggan menilai perusahaan berusaha memberikan yang terbaik untuk konsumen dengan selalu berusaha meningkatkan pelayanan dan produk mereka sesuai dengan yang dibutuhkan oleh pelanggan. Dengan terus meningkatnya inovasi yang dilakukan oleh perusahaan, maka kepuasan pelanggan dari PT. Holcim Beton Surabaya juga akan meningkat. Hasil pemaparan diatas membuktikan bahwa sebagian besar pelanggan dari PT. Holcim Beton Surabaya merasakan dampak inovasi yang sudah dilakukan oleh perusahaan, sehigga pelanggan merasa puas dengan apa yang sudah mereka dapatkan dari perusahaan.

\section{Pengaruh Orientasi Pasar Terhadap Kepuasan Pelanggan}

Makna temuan ini adalah dengan meningkatnya orientasi pasar yang dilakukan oleh PT. Holcim Beton Surabaya berdasarkan indikator orientasi pelanggan dan responsiveness, maka akan meningkatkan kepuasan pelanggan pada PT. Holcim Beton Surabaya. Hasil ini sesuai dengan hasil penelitian yang dilakukan oleh Liem Viet (2012) dan Ryu (2012) yang menyatakan bahwa orientasi pasar memiliki pengaruh terhadap kepuasan pelanggan.

Pelayanan yang baik dan berkualitas dari perusahaan kepada pelanggan, sering dianggap sebagai cara yang paling mudah untuk menggali informasi dari pelanggan tentang apa yang dibutuhkan oleh pelanggan saat ini. Dengan begitu perusahaan akan bisa menciptakan suatu produk yang sejalan dengan apa yang diinginkan oleh pelanggan, sehingga pelanggan menjadi bagian dari perusahaan 
dalam penciptaan produk-produk baru. Selain itu juga hubungan baik antara perusahaan dan pelanggan harus dijaga dengan baik, agar menimbulkan kepuasan bagi kedua belah pihak, baik perusahaan maupun pelanggan.

Dapat disimpulkan bahwa pelanggan sangat melihat bagaimana perusahaan menempatkan mereka dalam sudut pandang perusahaan. Ketika mereka mendapatkan informasi yang mereka cari, mendapatkan pelayanan yang baik, masukan mereka di terima, dan perusahaan mengerti apa yang pelanggan inginkan, maka dengan sendirinya perusahaan akan mendapatkan kepuasan dari pelanggan.

\section{Inovasi Berpengaruh Tidak langsung Terhadap Kepuasan Pelanggan Melalui Keunggulan Bersaing}

Hasil penelitian menunjukkan bahwa ketika PT. Holcim Beton Surabaya mampu melakukan atau meningkatkan inovasi dengan baik, maka keunggulan bersaing akan bisa dicapai atau didapatkan, yang berujung pada kepuasan pelanggan terhadap PT. Holcim Beton Surabaya akan semakin meningkat. Hasil penelitian ini sesuai dengan penelitian yang dilakukan oleh Tahir Naveed, et al (2012) yang menyatakan inovasi berpengaruh tidak langsung terhadap kepuasan pelanggan melalui keunggulan bersaing.

Keunggulan bersaing menjadi pertimbangan pelanggan untuk kepuasan mereka tehadap inovasi yang dilakukan oleh PT. Holcim Beton Surabaya. Pelanggan yang merasa bahwa inovasi yang dilakukan meliputi inovasi produk dan inovasi proses akan mengakibatkan kepuasan bagi mereka, menilai apa yang sudah dilakukan perusahaan sudah cukup baik. PT. Holcim Beton Surabaya dinilai pelanggan sudah melakukan sesuatu yang inovatif, yaitu menciptakan suatu produk yang belum ada di dalam perusahaan lain, serta produk yang sulit ditiru oleh pesaing. Tidak hanya berhenti sampai disitu saja, PT. Holcim Beton Surabaya dinilai oleh pelanggan selalu mengembangkan suatu produk yang inovatif secara terus menerus, sehingga pelanggan bisa memilih produk yang sesuai dengan apa yang mereka inginkan atau perlukan.

Perusahaan dinilai pelanggan tidak hanya memperbarui atau menciptakan produk yang baru saja. Akan tetapi, perusahaan juga dinilai memperpaharui pelayanan mereka secara terus menerus, sehingga pelanggan merasa nyaman dalam bertransaksi atau melakukan apapun yang berhubungan dengan perusahaan. Dengan hal seperti ini, yang diuntungkan tidak hanya pelanggan, tetapi juga PT. Holcim Beton Surabaya. Dengan persepsi yang diperoleh oleh pelanggan ini, maka keunggulan bersaing sudah di dapatkan oleh perusahaan di mata pelanggan, dimana perusahaan lain belum melakukan hal yang sudah dilakukan oleh PT. Holcim Beton Surabaya terhadap mereka. Dengan begitu bisa dikatakan bahwa kepuasan dari pelanggan bisa di dapatkan melalui keunggulan bersaing yang berawal dari inovasi yang baik dari perusahaan.

\section{Orientasi Pasar Berpengaruh Tidak langsung Terhadap Kepuasan Pelanggan Melalui Keunggulan Bersaing}

Hasil penelitian menunjukkan bahwa keunggulan bersaing dapat menjadi mediasi pengaruh orientasi pasar terhadap kepuasan pelanggan. Hasil penelitian menunjukkan bahwa ketika PT. Holcim Beton Surabaya mampu melakukan atau meningkatkan orientasi pasar dengan baik, maka keunggulan bersaing akan bisa dicapai atau didapatkan, yang berujung pada kepuasan pelanggan terhadap PT. Holcim Beton Surabaya akan semakin meningkat.

Keunggulan bersaing menjadi pertimbangan pelanggan untuk kepuasan mereka tehadap orientasi pasar yang dilakukan oleh PT. Holcim Beton Surabaya. Pelanggan yang merasa bahwa orientasi pasar yang dilakukan meliputi orientasi pelanggan dan responsiveness akan mengakibatkan kepuasan bagi mereka, menilai apa yang sudah dilakukan perusahaan sudah cukup baik. Perusahaan dinilai pelanggan sudah memiliki komitmen terhadap mereka, meliputi layanan yang berkualitas, memberi perhatian, serta tidak mengabaikan perubahan kebutuhan dari pelanggan. Mengingat pelanggan adalah aspek yang penting dalam kehidupan perusahaan, halhal kecil seperti yang sudah disebutkan diatas harus menjadi perhatian khusus bagi perusahaan untuk tetap mendapatkan perhatian dari pelanggan.

Dengan persepsi yang diperoleh oleh pelanggan ini, maka keunggulan bersaing sudah di dapatkan oleh perusahaan di mata pelanggan, dimana perusahaan lain belum melakukan hal yang sudah dilakukan oleh PT. Holcim Beton Surabaya terhadap mereka. Dengan begitu bisa dikatakan bahwa kepuasan dari pelanggan bisa 
di dapatkan melalui keunggulan bersaing yang berawal dari orientasi pasar yang baik dari perusahaan.

\section{KESIMPULAN}

Berdasarkan hasil analisis data dan pembahasan terkait dengan inovasi, orientasi pasar, keunggulan bersaing dan kepuasan pelanggan PT. Holcim beton Surabaya, maka kesimpulan penelitian ini adalah :

1. Inovasi secara langsung memiliki pengaruh signifikan terhadap keunggulan bersaing. Inovasi dalam hal ini diwujudkan melalui inovasi produk dan inovasi proses. Pada saat perusahaan melakukan inovasi yang terus menerus, maka dapat dikatakan mereka akan selalu memiliki keunggulan bersaing dibandingkan dengan perusahaan yang stagnan dan tidak melakukan inovasi.

2. Orientasi pasar secara langsung memiliki pengaruh signifikan terhadap keunggulan bersaing. Keunggulan bersaing dalam hal ini meliputi kemampuan bersaing, sumber daya manusia, dan relationship marketing. Ketika perusahaan memperhatikan apa yang di inginkan oleh konsumen, maka dengan sendirinya perusahaan tersebut mempunyai keunggulan bersaing di mata para pelanggan.

3. Inovasi secara langsung memiliki pengaruh signifikan terhadap kepuasan pelanggan. Dalam penelitian ini menunjukkan pengaruh inovasi terhadap kepuasan pelanggan adalah berbanding lurus, yaitu semakin baik/tinggi inovasi akan semakin baik/tinggi pula kepuasan pelanggan.

4. Orientasi pasar memiliki pengaruh signifikan terhadap kepuasan pelanggan. Hal ini menunjukkan pengaruh orientasi pasar terhadap kepuasan pelanggan adalah berbanding lurus, yaitu semakin baik/tinggi orientasi pasar akan semakin baik/tinggi pula kepuasan pelanggan.

5. Keunggulan bersaing terbukti dapat menjadi mediasi antara inovasi dan orientasi pasar terhadap kepuasan pelanggan. Hasil penelitian ini memberikan makna, apabila inovasi semakin baik maka diikuti dengan keunggulan bersaing, yang pada akhirnya dapat berdampak pada kepuasan pelanggan. Temuan ini memberikan bukti bahwa inovasi merupakan determinan penting keunggulan bersaing. Semakin baik inovasi yang dilakukan maka kepuasan pelanggan akan semakin meningkat melalui keunggulan bersaing. Begitu juga hal ini berlaku untuk orientasi pasar.

\subsection{Saran}

Berdasarkan temuan hasil, maka saran difokuskan pada variabel kualitas layanan, kepuasan, sikap loyal dan perilaku loyal. Saran yang dapat dikemukakan sebagai berikut :

1. PT. Holcim Beton Surabaya harus selalu meningkatkan inovasi, yaitu inovasi produk maupun inovasi proses sehingga mampu meningkatkan keunggulan bersaing mereka di mata pelanggan.

2. PT. Holcim Beton Surabaya harus selalu menggunakan orientasi pasar untuk mendapatkan keunggulan bersaing. Karena dengan selalu memperbaiki orientasi pelanggan dan responsiveness secara otomatis mereka akan mendapatkan keunggulan bersaing yang di inginkan.

3. PT. Holcim Beton Surabaya diharapkan selalu melakukan inovasi untuk selalu mendapatkan kepuasan konsumen. Hal ini dikarenakan inovasi yang terus menerus akan menarik perhatian pelanggan, dan ketika inovasi yang diciptakan oleh perusahaan sesuai dengan harapan pelanggan, secara otomatis kepuasan pelanggan juga akan semakin tinggi.

4. PT. Holcim Beton Surabaya diharapkan meningkatkan orientasi pasar untuk meningkatkan kepuasan pelanggan. Dimana ketika orientasi pasar ini dilakukan yang meliputi orientasi pelanggan dan responsivenes, maka pelanggan merasa di perhatikan dan menjadi bagian dari perusahaan, sehingga ketika ini dilakukan, maka kepuasan pelanggan juga akan di dapatkan.

5. PT. Holcim Beton Surabaya diharapkan bisa menjaga serta meningkatkan keunggulan bersaing mereka. Karena, keunggulan bersaing ini juga bisa menjadi mediasi antara inovasi dan orientasi pasar yang mempengaruhi kepuasan pelanggan.

\section{DAFTAR PUSTAKA}

Abdillah, W. dan Jogiyanto, H. M.,2009. Konsep Dan Aplikasi PLS (Partial Least Square) Untuk Penelitian Empiris. Badan Penerbit Fakultas Ekonomi Dan Bisnis UGM, Yogyakarta.

Baker., Sinkula., 2013. The Synergistic Effect of market oriented and learning organization on organization performance. 
Journal of The Academy of Marketing Science. Vol. 27, P. 411-427.

Casidy, Riza, 2014. The role of perceived market orientation in the higher education sector. Journal of The Academy of Marketing Science. Vol. 233, P. 232-235

Castro, Carmen Barroso, Enrique M, \& David M. 2004. The influence of employee citizenship behaviour on customer loyalty. Journal of service industry management vol 15 no. 1 pp. 27-54

Hurley and G. Thomas, M. Hult., 2013. Innovation, Market Orientation, and Organization Learning : An Integration and Empirical Examination. Journal of Marketing. Vol 62 Juli 1998. Pp 42-54.

Husein, Umar, 2000. Metodologi Penelitian, Aplikasi dalam Pemasaran, PT. Gramedia Pustaka Utama, Jakarta.

Jaworski, B.J, dan Kohli A.K. 1993. Market orientation: antecedents and consequences. Journal of Marketing, Vol. 57, pp. 53-70.

Kevin, Ferry Jie, 2013. Investigating The Impact of innovation on Customer Loyalty in Mobile Telephony in Greece. The TQM Journal, Vol. 22 Iss: 3 pp. 330 - 343.

Kevin Zheng Zhou, James R. Brown \& Chekitan S. Dev. 2009. Market orientation, competitive advantage, and performance: A demand-based perspective. Journal of Business Research 62 1063-1070

Kotler, P. dan Keler, K.L. 2009. Marketing Management, Thirteenth Edition. Sabran, B. (penerjemah). Manajemen Pemasaran, Edisi ke Tiga Belas, Jilid 1. Jakarta: Penerbit Erlangga.

Liem Viet Ngo, Aron O'Cass. 2012. In Search of Innovation and Customer-related Performance Superiority: The Role of Market Orientation, Marketing Capability, and Innovation Capability Interactions. Journal of Marketing, Vol. 57, pp. 53-70.

Nadia, Nurul and Abdul Aziz 2016. Direct Effect of innovation on Customer Satisfaction and Customer Loyalty in Nigerian Islamic Bank. Management, Vol 3 (1) : 6-11. Universiti Utara Malaysia.
Naveed, Tahir, Irum Akhtar, and Khaliq ur Rehman C, 2012. Perceived Service and Food Quality, Satisfaction and Behavioral Intentions in Senior Retirement Communities. Journal of The Academy of Marketing Science. Vol. 12, P. 411-427

Oly, Nelson dan Chan, Kok Wah. 2005. Factorial and Dscriminant Analyses of The Underpinning of Relationship Marketing and Customer Satisfaction. International Journal of Bank Marketing. 23 (7) 524557

Porter, Michael, E., 2008. "Comvetitif Strategy". The Free Press, New York. p.20. Singarimbun, Masri. 1991. Metode Penelitian, Yogyakarta : LP3S.

Ryu, Kisang, Hye-Rin Lee, Woo Gon. 2012. The Influence of The Quality of The Physical Environment, Food, and Service on Restaurant Image, Customer Perceived Value, Customer Satisfaction, and Behavioral Intentions. International Journal of Contemporary Hospitality Management, Vol. 24 Iss: 2 pp. 200-223.

Santouridis, Ilias dan Trivellas, Panagiotis. 2010. Investigating The Impact of Service Quality And Customer Satisfaction on Customer Loyalty in Mobile Telephony in Greece. The TQM Journal, Vol 22 p. 330343

Silvadas, Douglas W \& Dwyer. (2010). Benchmarking Marketing Capabilities for Sustainable Competitive Advantage. Journal of Marketing. Vol. 69 p. 80-94.

Slater, Stanley., F. and Jhon. C. Narver., 2008. Market Orientation and the Learning Orgnization. Journal of Marketing. Vol 59 p. 63-74.

Tjiptono, Fandy dan Chandra, Gregorius.2007.Service Quality and Satisfactions. Edisi ke-2. Andi. Yogyakarta

Tsao, Wen-yu. 2014. Enhancing competitive advantages: The contribution of mediator and moderator on stickiness in the LINE. Journal of Retailing and Consumer Services. Vol 21 p. 933-941 